\title{
STATE SOVEREIGNTY IN THE CURRENT ECONOMIC CONTEXT
}

\author{
Daniel SOLESCU \\ “Nicolae Bălcescu" Land Forces Academy, Sibiu, Romania \\ danielsolescu@yahoo.com
}

\begin{abstract}
Globalization has raised the issue of the place and role of the nation state in the world market. The effects of globalization have resulted in the joint effort of some State's sovereign powers, quite exclusive until recently, which leads to reconsider the concept of state sovereignty, tasks, functions and objectives of the state. Globalization involves reducing the state intervention in the economic matters, but it does not imply the disappearance of the state concept. The integration in the transnational economy necessarily implies the weakening of the nation-state authority, since it must make room for the independent actors.
\end{abstract}

\section{Keywords: state sovereignty, globalization}

\section{Introduction}

The nation-state has been stated, as the main political institution in Europe, especially after the French Revolution. Following the disintegration of the multinational empires and colonial empires after the two world wars, the nation-state has become the normative model in terms of the international relations, monopolizing the world political stage.

Since the Peace of Westphalia (1648) and especially since the French Revolution (1789), the affirmation ofthe nation-states and their imposition, as leading players, in the international relations, was mostly an affirmation of their sovereignty where the modern nation-state is formed based on the claim of sovereignty.

\section{Sovereignty of the international relations}

In 1975, according to the Dictionary of the Romanian Language, the supreme sovereignty refers to an authority without limits. The same dictionary defined the national sovereignty as an independence from the other states' power, while the state sovereignty referred to the independence from the other states, namely the supremacy of state power within the country.

In terms of the international relations, sovereignty means independence. At the same time, the state sovereignty is the source that governs under international laws. But these powers are not unlimited, they are not subjected to any rule limits, but these are imposed by the needs arising from the coexistence of States as subjects of the international law. Therefore, ever since the era, in which the states are doomed to coexistence, there is no such thing as unlimited, absolute sovereignty.

In 1992, Ion Deleanu defines sovereignty as misappropriation of the state power that expresses the right of this power to organize, to exercise, to establish and solve internal and external problems, freely, and according to his will, without any interference, respecting the sovereignty of the other states and of the public international law [1].

Three elements of the above definitions should be considered: 
State sovereignty is claiming to be the last and sole political authority;

This type of authority is exercised within a defined territory - so sovereignty is closely linked to territoriality;

Mutually recognized sovereignty of the states is the foundation of the international system.

Sovereignty remained an eminently linked state notion. From the perspective of public international law, the state continues to be the only legal entity that is both sovereign and directly reports to the international law. Until the state does not waive his direct subordination to international law, it still retains sovereign statehood. However, the extent of sovereignty, components (sovereign powers) and its embodiments are constantly changing, depending on the state, on the contents of the man and citizen's fundamental rights and freedoms, on the international obligations assumed by the state, on the various integration relations, on the planned or unplanned circumstances, or on the internal and external ones (e.g., epidemics, economic collapses, catastrophes, global or national incidents, manifestations of other states, threat of war, etc.).

Globalization has raised the issue of the place and role of the nation state in the world market. According to some specialists, globalization entails while diluting the idea of nation-state and ultimately leads to the disappearance of the nation states. [2] All studies and books devoted to the globalization remember the weakening of the state power - a nation or a broadcasting authority of the state, but none explains this.

If we consider that the fulfillment of the important tasks of the modern state preserving the stability of the currency, the foreign trade balance, correcting the economic cycles, collecting the needed taxes to finance the public tasks, ensuring compliance with national laws, ensuring public safety - is almost impossible,in the circumstances of the state not being able to control them (falling of the stock markets, environmental disasters, acts of terrorism, weapons of mass destruction, trafficking in arms, drugs, human trafficking etc.), it is quite justified to have certain unifying force states which tend to try to stop or even brake their joint action. The effects of globalization have resulted in the joint exercise of some, until recently, exclusive sovereign powers of the State, which leads to reconsider the concept of state's sovereignty, tasks, functions, and objectives.

In the places where the states were once the masters of markets, the markets are now, in many crucial issues, the leading national governments. The progressive integration of the world economy, through international production, has shifted the balance of power from the states to the international markets. The states' authority decline is reflected by a growing diffusion of authority towards other institutions and associations, towards regional bodies, as well as towards a growing asymmetry between the larger countries and the smaller ones.

The weakening of the authority of all governments, that we feel today, is due to the financial and technological exchanges and due to the accelerated integration of national economies into a single global market economy (which is the fundamental factor of globalization). But in fact, before this, governments' failure was precisely due to the free markets. Willingly or unwillingly, the governments had failed in an attempt to govern the national economy to maintain a low unemployment rate and supportthe economic growth, as to reduce the deficit in the balance of payments with the other states, as to controlthe interest rates or the foreign exchange rates, in other words, in the effort to have opened the national markets, thus giving in to the pressures made by international financial institutions.

Not coincidentally, one of the best analysts of globalization, the British Susan Strange, 
has entitled one of her books The Retreat of The State. The state basically provides a framework of legal rights and duties, but inside the others increasingly affectthe results.

Certain member powers were transferred to non-territorial transnational companies in, at least, four areas [3].

$>$ States withdrew collectively participation in ownership and control of industry, services and trade and even guidance on research and innovation in technology.

$>$ In the last decade, transnational corporations have done more than the states and the international organizations themselves, for the redistribution ofthe wealth from the developed industrialized countries towards the poorer, developing ones. Trade and investment have created many more jobs and have done more to raise the living standards of people than official aid programs.

$>$ In the important area of managementstaff relations, transnational companies have come to take over the lead role from governments in solving or, at least, overseeing conflicts of interest. Rather than fight for wages and working conditions, in the context of state laws on industrial relations, a much larger part of the agreement is now within the company.

$>$ In terms of the fiscal problems, companies have increasingly escaped from taxation of the profit, levied by governments themselves and act in some respects as collecting taxes and revenue. They charge, accumulate income from their operations in the global economy and then take important political decisions on how to allocate this revenue.

That government of all countries, large and small, strong and weak, was diminished as a result of the technological and financial and accelerated integration of national economies into a single global market economy. The nation-state has ceased to be an effective economic manager. It became less autonomous, has a less exclusive control over the economic and social processes within its boundaries and is less able to maintain the national peculiarities and cultural homogeneity [4].

\section{Sovereignty at the present times}

At the beginning of the $21^{\text {st }}$ century, countries are increasingly more interdependent in everything they undertake. For now it is difficult to analyze the long-term effect of globalization on the international community, but it is clear that globalization has both a positive and negative impact. The positive side of this process is that it will increase the interaction between countries, which in turn opens up new possibilities for developing human civilization, especially in the economic sphere. Increased trade, investment and technology between different regions, facilitating contacts between people, familiarity with other cultures are certainly beneficial for mankind. This interaction strongly and deeply manifests itself in content ratio between national security and international security. Thus, we will see more and more increasing influence of international security on national security, due to rising global community's role in crisis management, in any way [5].

In March 1997, in Salzburg, Austria, it was held the $50^{\text {th }}$ International Seminar of Political Science, devoted to analysis of state institution towards future transformations produced by globalization.

The main question asked in this debate was whether the state and especially the national, is at the end of its "career", of its long about 500 years, due to globalization economy, ethnic rivalries and religious and reconfirmation of world power centers. The answer given to these challenging questions by the representatives from 32 countries, both developed and powerful, and also less developed and strong was almost unanimously negative. [6]

Things cannot be working without a State. State, this venerable invention, national or post-national has yet a secured 
future - most analysts believe.If not from ant other reason, at least from the simple reason that, like democracy, humanity has yet to invent something better to put replace. [7]

Integration into transnational economy of necessity involves weakening the nation-state authority, since it must place independent actors. Transnational corporations exert a significant influence on national economic exchanges, on subregional and international ones, in addition, the common people of the same ethnic origin, speaking the same language or dialects took in increasing numbers can move freely across borders. Therefore, the boundaries of today have lost their character became impenetrable and extremely elastic [8].

The idea of the abandonment of part of the national sovereignty has often a loaded impact of "patriotic emotion and reactions to adversity." Alvin Toffler does not forget that many countries have won their national independence and sovereignty after World War II, and others, even sooner, after the collapse of the Soviet Russian Empire and of the European communism. However, they are in a lower stage of development, compared to the developed country states, whose existence exceeds 300 years, now being in full informational revolution.

It is precisely these different social states that explain why, "in large areas of the world, national movements are amplified - exactly when the nation state is attacked more strongly in the name of globalization and planetary consciousness" - and why, "while poets and intellectuals of the economically backward regions write national anthems, the Member of third wave are looking for the virtues of the borderless world" [9].
In conclusion, globalization involves the reducing of the state interventionism, but not the disappearance of the idea of the state, whose role would be the very development and implementation of the national economic policies. With globalization, freedom of the State, in terms of issuing the economic policy, is more reduced due to the high interdependence of national economies and implicitly to the other economic policy decisions of other states, to the limitations imposed by national barriers amongeconomies and also by the limits imposed by the increasing of the economic openness.

States are not the only "actors" on the stage of the international relations and, sometimes, not even the most important one. States are no longer homogeneous actors. Mostly, they do not represent a united front based on a consensus in the national interest. They negotiate with other governments and at the same time or especially internally with their constituents and labor, to stay in power. As a result, governments have a weak domestic position, cannot act as a decisively on the external affairs, as well as a solid government. Member state's positions in the international negotiations can be determined, to a large extent, by the balance of the political forces within the country.

The fact that state authority passes a period of diffusion is not new on the agenda. Let us not forget that the nature of the state was subject to change on the occasion of the major social revolutions or wars, for example. The novelty is that, in a relatively short period of time (20-30 years), the overwhelming majority of states pass, at the same time, through the same kind of substantial changes.

\section{References}

[1] Ion Deleanu, Drept constituţional şi instituţii politice, (Iaşi, „Chemarea” Publishing House Foundation vol. II., 1992), 39;

[2] Daniel Bădulescu, Globalizarea şi băncile, (Bucharest, Economic Publishing House, 2007), 31; 
[3] Susan Strange, Retragerea statului. Difuziunea puterii în economia mondială, (Bucharest, Trei Publishing House, 2002), 66-88;

[4] Paul Hirst, Grahame Thompson, Globalizarea sub semnul intrebării: Economia internaţională şi posibilităţi de guvernare, (Bucharest, Trei Publishing House, 2000), 361 ;

[5] Petre Duţu, "Geopolitici şi geostrategii pe traiectoria viitorului”, "Impact Strategic", No.1/2005;

[6] TeodorFrunzeti, Globalizareasecurităţii, (Bucharest, Military Publishing House, 2006), 14

[7] Ion A. Popescu, Aurelian A. Bondrea, Mădălina I. Constantinescu, Globalizarea: mitşirealitate, (Bucharest, Economic Publishing House, 2004), 254;

[8] Chai-Anan Samudavanija, "Schimbareaordiniiglobale", (Bucharest, AntetPublishing House, 2002)

[9] Alvin Toffler - Război şi antirăzboi, (Bucharest, Antet Publishing House, 1995), 284 